Anaesthesist 2019 $\cdot 68: 15-21$ https://doi.org/10.1007/s00101-018-0506-6 Received: 14 February 2018

Revised: 2 October 2018

Accepted: 9 October 2018

Published online: 7 November 2018

(c) The Author(s) 2018

CrossMark

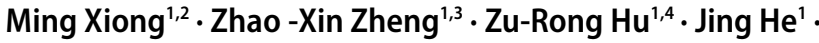 \\ Uchenna Madubuko ${ }^{2} \cdot$ Dennis Grech $^{2} \cdot$ Xing-An Zhang ${ }^{1} \cdot$ Bo Xu$^{1}$ \\ 'Department of Anesthesiology, General Hospital of Southern Theatre Command of PLA, Guangzhou, \\ China \\ ${ }^{2}$ Department of Anesthesiology \& Peri-Operative Medicine, New Jersey Medical School, Rutgers, USA \\ ${ }^{3}$ Department of Anesthesiology, Zhongshan Hospital Affiliated to Xiamen University, Xiamen, China \\ ${ }^{4}$ Department of Anesthesiology, Guangdong Province Hospital for Women and Children Health Care, \\ Guangzhou, China
}

\title{
Propofol-sparing effect of different concentrations of dexmedetomidine
}

\section{Comparison of gender differences}

\section{Introduction}

Propofol is a sedative and hypnotic agent commonly used for the induction and maintenance of general anesthesia because of its rapid onset and offset of effect. Dexmedetomidine, a useful and safe adjuvant in propofol anesthesia, is an $\alpha_{2}$ adrenoceptor agonist that provides sedation, anxiolysis, and analgesia. It has been shown that dexmedetomidine can blunt the cardiovascular response to tracheal intubation during propofol-based anesthesia $[1,2]$. In addition, dexmedetomidine is frequently used to decrease propofol requirement and the incidence of postoperative delirium in propofol anesthesia $[3,4]$. Hence, dexmedetomidine and propofol are often coadministered in general anesthesia.

Many studies have shown that the pharmacodynamics of drugs, for example propofol, are influenced by gender [5-7]. A recent study showed that male patients needed higher calculated effect-site median effective concentration $\left(\mathrm{EC}_{50}\right.$, the concentration at which $50 \%$ of patients experience loss of consciousness, LOC) of propofol than female patients during supraglottic airway insertion in coadministration with $0.5 \mu \mathrm{g} / \mathrm{kg}$ body weight

Ming Xiong and Zhao-Xin Zheng contributed equally to this work.
(BW) dexmedetomidine [8]. Based on these findings, gender should be considered during propofol anesthesia. Previous studies have shown that dexmedetomidine could reduce the calculated effectsite $\mathrm{EC}_{50}$ of propofol in a dose-dependent manner [9, 10]; however, it is not known if there is any gender disparity on the calculated effect-site $\mathrm{EC}_{50}$ of propofol during coadministration of different concentrations of dexmedetomidine. Therefore, the purpose of this study was to compare gender differences on the propofolsparing effect of different concentrations of dexmedetomidine.

\section{Material and methods}

\section{Subject selection}

This study was approved by the Guangzhou General Hospital of PLA and was registered in ClinicalTrials.gov (registration number: NCT02853864). After obtaining written informed consent, 60 male and 60 female patients with an age range of 20-50 years old, an American Society of Anesthesiologists (ASA) score I-II and body mass index (BMI) of $18.0-25.0 \mathrm{~kg} / \mathrm{m}^{2}$, were enrolled in the study. Excluded were patients with history of mental disorders, hearing impairment, severe systemic illness, substance abuse and bradyarrhythmia.
A randomization sequence was used to allocate both male and female patients to 4 dexmedetomidine concentration groups (0.0, 0.4, 0.6, and 0.8). Thus, there were a total of 8 groups each consisting of 15 subjects in this study.

\section{Protocol}

A Philips MP30 monitor (Philips, Boeblingen, Germany) was used for measuring non-invasive mean arterial pressure (MAP), heart rate (HR), and the oxyhemoglobin saturation $\left(\mathrm{SpO}_{2}\right)$ while a facemask delivered oxygen at a rate of $31 / \mathrm{min}$. Bispectral index (BIS) values were monitored with Aspect Vista ${ }^{\mathrm{TM}}$ (Model A2000, BIS Aspect Medical Systems; Natick, MA, USA). The MAP was recorded every $3 \mathrm{~min}$ or after manual activation. The $\mathrm{HR}, \mathrm{SpO}_{2}$, and BIS values were monitored continuously. Patients were made non-peros (NPO) per ASA protocol. The forearm was used as the intravenous site to administer all drugs. Propofol was administered through target-controlled infusion (TCI) using a Fresenius infusion pump (Fresenius), with the PK-PD model of Schnider et al. [11]. Dexmedetomidine was given via TCI using a SN-50 infusion pump (Sino Medical-Device Technology) driven by STANPUMP software $[12,13]$. 


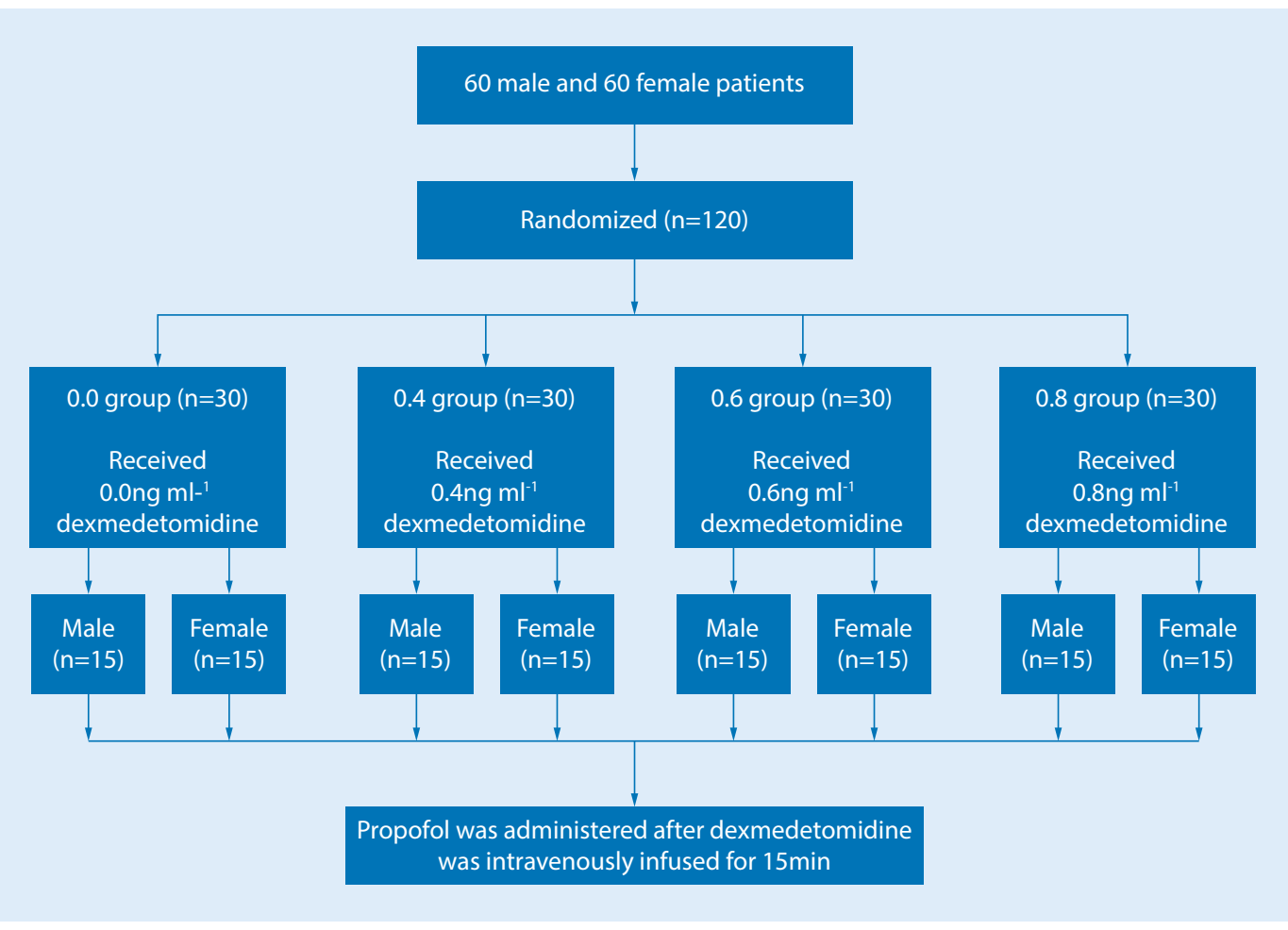

Fig. 14 Disposition of the study patients
Patients were allocated to receive no dexmedetomidine in the $0.0 \mathrm{ng} / \mathrm{ml}$ group, a targeted effect-site concentration of dexmedetomidine $0.4 \mathrm{ng} / \mathrm{ml}$ in the 0.4 group, $0.6 \mathrm{ng} / \mathrm{ml}$ dexmedetomidine in the 0.6 group and $0.8 \mathrm{ng} / \mathrm{ml}$ dexmedetomidine in the 0.8 group by an independent observer blinded to the targeted dexmedetomidine concentration. Propofol was administered after dexmedetomidine had been infused intravenously for $15 \mathrm{~min}$. (• Fig. 1) The propofol administration was set to provide an initial effect-site concentration of $1.0 \mu \mathrm{g} / \mathrm{ml}$, followed by increments of $0.2 \mu \mathrm{g} / \mathrm{ml}$ when the effect-site concentration and target concentration of propofol were balanced. After observing closure of patient's eyes, the observer's assessment of alertness/sedation scale (OAA/S) score was evaluated every $30 \mathrm{~s}$ [14] by an independent observer blinded to the dexmedetomidine concentration. An OAA/S score $<2$ was regarded as LOC (absence of response to mild prodding or shaking) [15]. This study was terminated after LOC.

\section{Measurements}

The calculated effect-site $\mathrm{EC}_{50}$ concentration of propofol and BIS were recorded following LOC.

\section{Statistical analysis}

Statistical analysis was performed using SPSS 20.0. Results are expressed as mean and standard deviation (SD) if the data passed the normality test or, alternatively, as median and interquartile range. The one-way analysis of variance (normal data) or Jonckheere-Terpstra test for nonnormal data was used to evaluate differences between groups. The ASA physical status was analyzed with the Fisher exact probability method. The $\mathrm{EC}_{50}$ and $\mathrm{BIS}_{95}$ (the BIS at which $95 \%$ of the patients achieved LOC) values were calculated using probit analysis. Comparison of $\mathrm{EC}_{50}$ between males and females in each dose group were analysed by use of the Mann-Whitney U-test.

The mechanistic model of pharmacodynamic interaction was used to determine whether the interaction between dexmedetomidine and propofol was nonadditive or additive via unweighted least- squares nonlinear regression. The model [16] is described by equation A1:

$$
\begin{aligned}
& \mathrm{EC}_{\mathrm{p}} / \mathrm{EC}_{50 \mathrm{p}}+\mathrm{EC}_{\mathrm{d}} / \mathrm{EC}_{50 \mathrm{~d}} \\
& +\delta \cdot\left(\mathrm{EC}_{\mathrm{p}} / \mathrm{EC}_{50 \mathrm{p}}\right) \cdot\left(\mathrm{EC}_{\mathrm{d}} / \mathrm{EC}_{50 \mathrm{~d}}\right)=1
\end{aligned}
$$

where $\mathrm{EC}_{\mathrm{p}}$ is the effect-site concentration of propofol for LOC, EC $d$ is the plasma concentration of dexmedetomidine for LOC, $\mathrm{EC}_{50 \mathrm{p}}$ is the effect-site $\mathrm{EC}_{50}$ of propofol for LOC when it was given as a sole agent, $\mathrm{EC}_{50 \mathrm{~d}}$ is the dexmedetomidine plasma concentration at which $50 \%$ of patients lost consciousness when it was administered as a sole drug and $\delta$ is a dimensionless parameter characterizing the shape of the curve (with $\delta \neq 0$ if the result is a curved line suggesting nonadditive interaction and $\delta=0$ if the result is a straight line suggesting additivity).

The possibility of an additive interaction between dexmedetomidine and propofol was examined by the following equation [16] (derived from equation $\mathrm{A} 1$, assuming $\delta=0)$ :

$$
\mathrm{EC}_{\mathrm{p}}=\mathrm{EC}_{50 \mathrm{p}}-\mathrm{EC}_{\mathrm{d}} \cdot \mathrm{EC}_{50 \mathrm{p}} / \mathrm{EC}_{50 \mathrm{~d}}
$$

The possibility of a nonadditive effect was examined by the following equation 
Anaesthesist 2019.68:15-21 https://doi.org/10.1007/s00101-018-0506-6

(c) The Author(s) 2018

M. Xiong · Z. -. Zheng · Z.-R. Hu · J. He - U. Madubuko · D. Grech · X.-A. Zhang · B. Xu

\section{Propofol-sparing effect of different concentrations of dexmedetomidine. Comparison of gender differences}

\section{Abstract}

Background. The pharmacodynamics of propofol are closely linked to gender. Dexmedetomidine can decrease propofol needs during propofol anesthesia. The aim of this study was to compare the gender differences on the calculated effect site median effective concentration ( $\mathrm{EC}_{50}$ ) of propofol for loss of consciousness (LOC) after pretreatment with different concentrations of dexmedetomidine.

Methods. In this study 60 male and 60 female patients were randomly allocated to receive dexmedetomidine at target plasma concentrations of $0.0 \mathrm{ng} / \mathrm{ml}$ ( 0.0 group), $0.4 \mathrm{ng} / \mathrm{ml}$ (0.4 group), $0.6 \mathrm{ng} / \mathrm{ml}$ (0.6 group) and $0.8 \mathrm{ng} / \mathrm{ml}$ (0.8 group). Propofol was administered after dexmedetomidine had been intravenously infused for $15 \mathrm{~min}$. The propofol infusion was targeted to provide an initial effect-site concentration of $1.0 \mu \mathrm{g} / \mathrm{ml}$, followed by increments by $0.2 \mu \mathrm{g} / \mathrm{ml}$ when the effect-site concentration and target concentration of propofol were in equilibrium until LOC was established, where LOC was defined by the observer's assessment of alertness/sedation scale (OAA/S) score $<2$. Results. The calculated effect-site $\mathrm{EC}_{50}$ of propofol LOC was higher in males than in females in the $0.0,0.4,0.6$, and 0.8 groups ( 2.43 vs. $2.17,1.99$ vs. $1.82,1.72$ vs. 1.56 and $1.50 \mathrm{vs} .1 .32 \mu \mathrm{g} / \mathrm{ml}$, respectively, all $p<0.05)$. The hypnotic interaction between dexmedetomidine and propofol could be described with an additive model of pharmacodynamic interaction.

Conclusion. Gender significantly influenced the calculated effect-site $\mathrm{EC}_{50}$ of propofol for LOC after pretreatment with different concentrations of intravenous dexmedetomidine. It was concluded that an additive interaction could describe the results seen. Thus, gender has to be considered when these drugs are coadministered.

Keywords

Pharmacodynamics - Comparative study - Loss of consciousness · Sedation · Bispectral index monitor

\section{Propofoleinsparung durch verschiedene Dexmedetomidinkonzentrationen. Vergleich geschlechtsassoziierter Unterschiede}

Zusammenfassung

Hintergrund. Die Pharmakodynamik von Propofol ist eng mit dem Patientengeschlecht verknüpft. Während einer Propofolanästhesie kann Dexmedetomidin den Propofolbedarf senken. Das Ziel dieser Studie war es, geschlechtsassoziierte Unterschiede der berechneten medianen effektiven Konzentration $\left(\mathrm{EC}_{50}\right)$ von Propofol für einen Bewusstseinsverlust (LOC) nach Vorbehandlung mit verschiedenen Konzentrationen von Dexmedetomidin zu ermitteln

Methoden. Je 60 männliche und weibliche Patienten wurden randomisiert einer von 4 Gruppen mit veschiedenen Dexmedetomidinzielkonzentrationen zugeordnet: $0,0 \mathrm{ng} / \mathrm{ml}$ (0,0 Gruppe), $0,4 \mathrm{ng} / \mathrm{ml}$ (0,4 Gruppe), $0,6 \mathrm{ng} / \mathrm{ml}$ (0,6 Gruppe) und 0,8 ng/ml (0,8 Gruppe).

Nach einer 15-minutigen intravenösen
Dexmedetomidininfusion wurde Propofol verabreicht. Die Propofolinfusion zielte auf eine initiale Konzentration am Wirkungsort von $1,0 \mu \mathrm{g} / \mathrm{ml} \mathrm{ab}$, gefolgt von Erhöhungen um $0,2 \mu \mathrm{g} / \mathrm{ml}$, wenn sich die Konzentration am Wirkungsort und die Zielkonzentration von Propofol im Gleichgewicht befanden, bis ein LOC bei einem OAA/S(Observer's Assessment of Alertness/Sedation Scale)-Score > 2 erreicht wurde.

Ergebnisse. Die berechnete Propofol$\mathrm{EC}_{50}$ am Wirkungsort für einen $\mathrm{LOC}$ war für Männern höher als für Frauen in den Gruppen $0,0,0,4,0,6$ und 0,8 ( 2,43 vs. 2,17; 1,99 vs. 1,$82 ; 1,72$ vs. 1,56 und 1,50 vs. $1,32 \mu \mathrm{g} / \mathrm{ml}$; alle $p<0,05)$. Die hypnotische Interaktion zwischen Dexmedetomidin und Propofol konnte mit einem additiven Modell einer pharmakodynamischen Interaktion beschrieben werden.

Schlussfolgerungen. Das Geschlecht beeinflusst die berechnete $\mathrm{EC}_{50}$ von Propofol für einen LOC am Wirkungsort nach der Vorbehandlung mit verschiedenen Konzentrationen von i.v. Dexmedetomidin signifikant. Ein additives Interaktionsmodell konnte die beobachteten Ergebnisse beschreiben. Daher muss bei der gemeinsamen Verabreichung dieser Medikamente das Geschlecht berücksichtigt werden.

\section{Schlüsselwörter}

Pharmakodynamik - Vergleichende Studie . Bewusstseinsverlust · Sedierung · Bispektrale Indexmonitor
[16] (derived from equation A1, assuming $\left.\delta^{\neq} \neq 0\right)$ :

$\mathrm{EC}_{\mathrm{p}}=\frac{\mathrm{EC}_{50 \mathrm{p}} \cdot\left(\mathrm{EC}_{50 \mathrm{~d}}-\mathrm{EC}_{\mathrm{d}}\right)}{\left(\mathrm{EC}_{50 \mathrm{~d}}+\delta \cdot \mathrm{EC}_{\mathrm{d}}\right)}$

where $\mathrm{EC}_{50 \mathrm{p}}, \mathrm{EC}_{50 \mathrm{~d}}$, and $\delta$ were calculated by nonlinear regression using the equation suggesting additivity and the equation suggesting a nonadditive effect. The residual sum of squares (RSS) of the curves was compared by an F-test to determine which curve correlated best with the data used in the analysis. If the RSS of the fitted curve from the equation suggesting additivity was lower than that from the equation suggesting nonadditivity, the interaction between dexmedetomidine and propofol was judged to be additive. If no differences between the RSS of the two curves were found, the equations suggesting additivity and nonadditivity were similar and $\delta$ was 0 ; therefore, the interaction between dexmedeto- midine and propofol was judged to be additive. If judged to be nonadditive, the isobolographic method was used to analyze whether the interaction was synergistic or antagonistic. Comparison of $\mathrm{EC}_{50 \mathrm{p}}$ and $\mathrm{EC}_{50 \mathrm{~d}}$ was analyzed by use of a t-test. $P<0.05$ was regarded as a significance level for all tests which were twotailed. 
Table 1 Demographics of the subjects participating in the study

\begin{tabular}{|c|c|c|c|c|c|}
\hline \multicolumn{2}{|c|}{ Dose group } & \multirow{2}{*}{$\begin{array}{l}{ }^{\text {a Age (years) }} \\
43.3(6.2)\end{array}$} & \multirow{2}{*}{$\begin{array}{l}{ }^{\mathrm{a}} \mathbf{B M I} \\
\left(\mathbf{k g} / \mathbf{m}^{2}\right)\end{array}$} & \multirow{2}{*}{$\begin{array}{l}\text { ASA (I/II) } \\
10 / 5\end{array}$} & \multirow{2}{*}{ 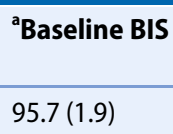 } \\
\hline 0.0 & Male & & & & \\
\hline & Female & $41.8(6.2)$ & $21.8(2.1)$ & $9 / 6$ & 96.9 (1.6) \\
\hline \multirow[t]{2}{*}{0.4} & Male & $41.1(7.8)$ & $22.3(1.9)$ & $9 / 6$ & $95.8(1.7)$ \\
\hline & Female & 44.3 (4.4.) & $22.8(1.9)$ & $11 / 4$ & $96.5(2.0)$ \\
\hline \multirow[t]{2}{*}{0.6} & Male & 41.7 (7.7) & $22.3(1.6)$ & $10 / 5$ & $96.1(1.7)$ \\
\hline & Female & 43.5 (4.6) & $22.6(2.0)$ & $11 / 4$ & $96.1(2.1)$ \\
\hline \multirow[t]{2}{*}{0.8} & Male & $40.1(7.3)$ & $23.1(1.7)$ & $9 / 6$ & $95.7(1.6)$ \\
\hline & Female & $42.5(6.7)$ & $21.8(1.6)$ & $11 / 4$ & $95.0(1.7)$ \\
\hline
\end{tabular}

BMI body mass index, ASA American Society of Anesthesiologists grade, BIS bispectral index ${ }^{\text {a}}$ Expressed as mean and SD

\section{Table 2 Propofol effect-site $\mathrm{EC}_{50}$ and $\mathrm{EC}_{95}$ for $\mathrm{LOC}$ according to group and gender}

\begin{tabular}{|c|c|c|}
\hline Dose group & $\mathrm{EC}_{50} / \mathrm{EC}_{95}(95 \% \mathrm{Cl})$ for males $(\mu \mathrm{g} / \mathrm{ml})$ & $\mathrm{EC}_{50} / \mathrm{EC}_{95}(95 \% \mathrm{Cl})$ for females $(\mu \mathrm{g} / \mathrm{ml})$ \\
\hline 0.0 & $2.43(2.36-2.49) / 3.01(2.87-3.26)$ & $2.17(2.11-2.23) / 2.64(2.50-2.90)^{d}$ \\
\hline 0.4 & $1.99(1.95-2.03) / 2.33(2.25-2.47)^{a}$ & $1.82(1.78-1.86) / 2.21(2.11-2.38)^{a}$ \\
\hline 0.6 & $1.72(1.68-1.76) / 2.05(1.97-2.18)^{a, b}$ & $1.56(1.52-1.59) / 1.86(1.78-2.00)^{a, b, c}$ \\
\hline 0.8 & $1.50(1.45-1.54) / 1.90(1.80-2.07)^{a, b, c}$ & $1.32(1.27-1.36) / 1.70(1.60-1.91)^{a, b, c, d}$ \\
\hline \multicolumn{3}{|c|}{$\begin{array}{l}\text { LOC loss of consciousness, } E C_{50} \text { effective concentration of propofol at which } 50 \% \text { of patients } \\
\text { experience loss of consciousness, } E C_{95} \text { effective concentration of propofol at which } 95 \% \text { of patients } \\
\text { experience loss of consciousness, } C l \text { confidence interval } \\
\text { a Significant difference compared with } 0.0 \text { group }(P<0.05) \\
\text { bSignificant difference compared with } 0.4 \text { group }(P<0.05) \\
\text { 'Significant difference compared with } 0.6 \text { group }(P<0.05) \\
\text { dS Significant difference between male and female patients }(P<0.05)\end{array}$} \\
\hline
\end{tabular}

Table 3 Estimated values of the concentrations of propofol and dexmedetomidine associated with $\mathrm{EC}_{50}$ for $\mathrm{LOC}$

\begin{tabular}{|c|c|c|c|c|c|}
\hline Interaction & $\begin{array}{l}\mathrm{EC}_{50 \mathrm{p}}(95 \% \mathrm{Cl}) \\
(\mu \mathrm{g} / \mathrm{ml})\end{array}$ & $\begin{array}{l}\mathrm{EC}_{50 \mathrm{~d}}(95 \% \mathrm{Cl}) \\
(\mathrm{ng} / \mathrm{ml})\end{array}$ & $\delta(95 \% \mathrm{Cl})$ & $\mathbf{R}^{2}$ & RSS \\
\hline Additivity $^{\mathrm{a}}$ & $2.50(2.39-2.60)$ & $2.06(1.78-2.33)$ & 0 & 0.71 & $3,000,285$ \\
\hline Nonadditivity $^{a}$ & $2.50(2.38-2.62)$ & $2.16(-0.04-4.36)$ & $0.08(-1.58-1.74)$ & 0.71 & $2,999,340$ \\
\hline Additivity $^{\mathrm{b}}$ & $\begin{array}{l}2.26 \\
(2.16-2.37)^{*}\end{array}$ & $2.09(1.79-2.40)$ & 0 & 0.67 & $2,969,093$ \\
\hline Nonadditivity $^{\mathrm{b}}$ & $2.25(2.13-2.37)$ & $1.62(0.58-2.67)$ & $-0.35(-1.13-0.43)$ & 0.68 & $2,962,124$ \\
\hline \multicolumn{6}{|c|}{$\begin{array}{l}R^{2} \text { the correlation coefficients for two possible interactions for } L O C, \Sigma \text { a dimensionless parameter } \\
\text { characterizing the shape of the curve, } R S S \text { the residual sum of squares, } E C_{50 p} \text { effective concentration } \\
\text { of propofol at which } 50 \% \text { of patients experience loss of consciousness, } E C_{50 d} \text { effective plasma } \\
\text { concentration of dexmedetomidine at which } 50 \% \text { of patients lost consciousness when administered } \\
\text { as a sole drug } \\
{ }^{*} P<0.05 \text { for comparison of } E C_{50} \text { between males and females } \\
{ }^{a} \text { Exploring the possibility of an additive or nonadditive interaction for male patients } \\
\text { b Exploring the possibility of an additive or nonadditive interaction for female patients }\end{array}$} \\
\hline
\end{tabular}

\section{Result}

\section{Patient characteristics}

All subjects completed the study. The characteristics of the patients are presented in Table 1. The eight groups were similar in terms of age, baseline
BIS, ASA physical status and BMI (all $P>0.05)$.

\section{Hemodynamics}

In groups 0.0 and 0.4 , following induction of LOC by propofol, HR and MAP continued to decline. The MAP at LOC significantly declined in the 0.6 group but $\mathrm{HR}$ remained stable. In the 0.8 group both HR and MAP remained stable at LOC. There were no significant differences between genders in any of the dose groups $(P>0.05)$ (• Fig. 2).

\section{Propofol EC 50 for LOC}

The calculated effect-site $\mathrm{EC}_{50}$ of propofol for LOC in male patients was $2.43 \mu \mathrm{g} / \mathrm{ml}$ (range $2.36-2.49 \mu \mathrm{g} / \mathrm{ml}$ ) in the 0.0 group, $1.99 \mu \mathrm{g} / \mathrm{ml} \quad(1.95-2.03 \mu \mathrm{g} / \mathrm{ml})$ in the 0.4 group, $1.72 \mu \mathrm{g} / \mathrm{ml}(1.68-1.76 \mu \mathrm{g} / \mathrm{ml})$ in the 0.6 group and $1.50 \mu \mathrm{g} / \mathrm{ml}(1.45-$ $1.54 \mu \mathrm{g} / \mathrm{ml}$ ) in the 0.8 group. The calculated effect-site $\mathrm{EC}_{50}$ of propofol for LOC in female patients was $2.17 \mu \mathrm{g} / \mathrm{ml}$ $(2.11-2.23 \mu \mathrm{g} / \mathrm{ml})$ in the 0.0 group, $1.82 \mu \mathrm{g} / \mathrm{ml} \quad(1.78-1.86 \mu \mathrm{g} / \mathrm{ml})$ in the 0.4 group, $1.56 \mu \mathrm{g} / \mathrm{ml}(1.52-1.59 \mu \mathrm{g} / \mathrm{ml})$ in the 0.6 group, and $1.32 \mu \mathrm{g} / \mathrm{ml}(1.27-$ $1.36 \mu \mathrm{g} / \mathrm{ml}$ ) in the 0.8 group. Female patients had a lower calculated effectsite $\mathrm{EC}_{50}$ of propofol for LOC compared with male patients in the 0.0 group, 0.4 group, 0.6 group, and 0.8 group (all, $P<0.05$ ) (• Table 2).

\section{Analysis of the interaction for LOC}

No significant differences were found between the RSS of the models exploring the possibility of a nonadditive or additive interaction between dexmedetomidine and propofol for male patients $(3,000,285$ vs. $2,999,340, P>0.05)$. The interaction for LOC between dexmedetomidine and propofol in males was judged to be additive. The RSS of the model exploring the possibility of an additive interaction between dexmedetomidine and propofol for female patients was similar to that of the model exploring the possibility of a nonadditive interaction (2,969,093 vs. $2,962,124, P>0.05)$. The interaction for LOC between dexmedetomidine and propofol in females was judged to be additive. The calculated effect-site $\mathrm{EC}_{50}$ of propofol for LOC was higher in males than in females $(2.43$ vs. $2.17 \mu \mathrm{g} / \mathrm{ml}$, $P<0.05)$. The calculated plasma $\mathrm{EC}_{50}$ of dexmedetomidine for LOC in males and females was similar (2.06 vs. $2.09 \mathrm{ng} / \mathrm{ml}$, $P>0.05$ ) (• Table 3). 

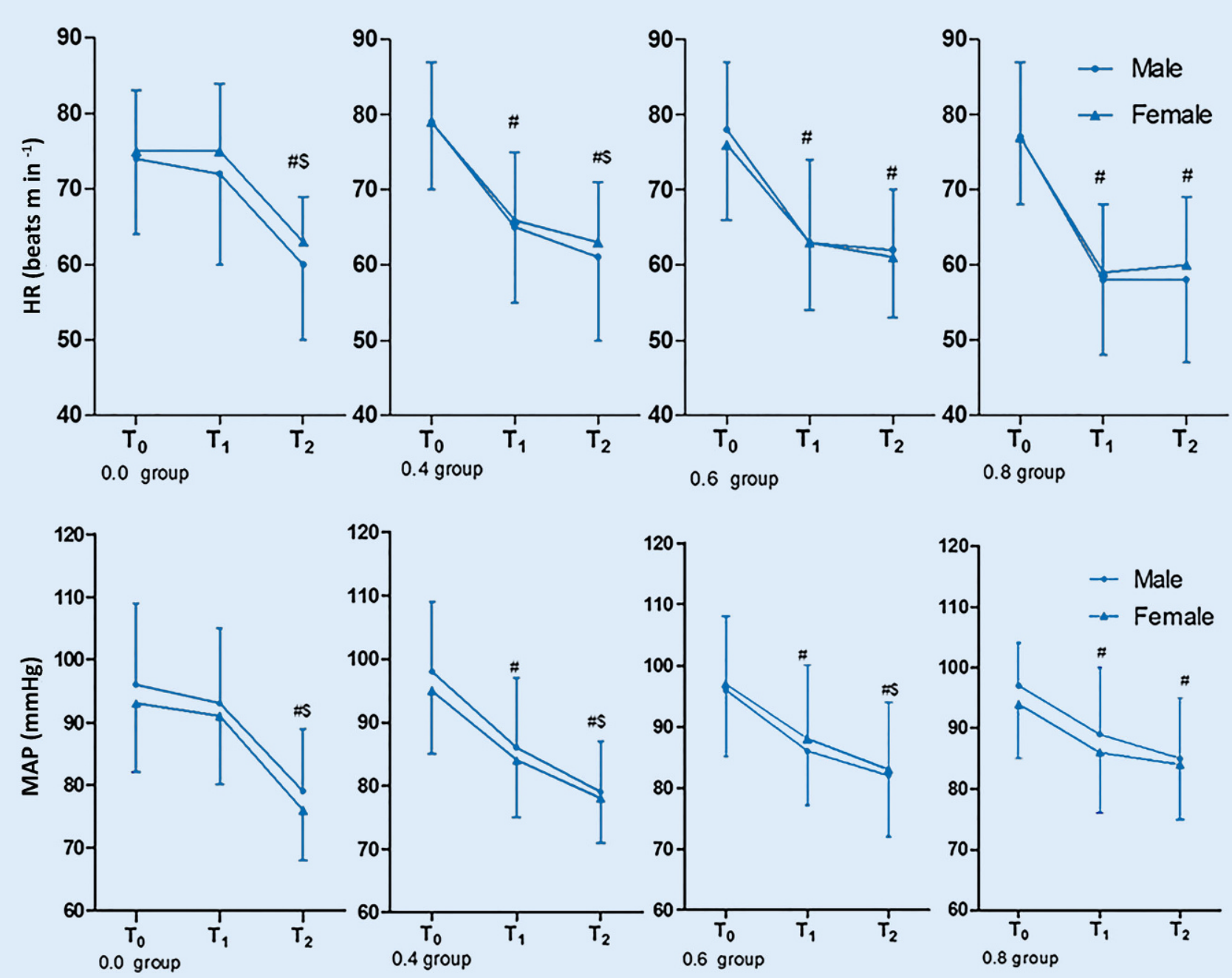

Fig. $2 \Delta$ Graphs showing comparisons of the heat rate (HR) and mean arterial pressure (MAP) between males and females in the four groups in the study. $T O$ is the time point at baseline, $T 1$ is the time point of starting the administration of dexmedetomidine for $15 \mathrm{~min}$, and $T 2$ is the time point of $L O C$. $\# P<0.05$ compared with TO, $\$ P<0.05$, comparison of HRand MAP between $\mathrm{T} 1$ and $\mathrm{T} 2$ in males and females

\section{$\mathrm{BIS}_{95}$ for LOC}

The Bis 95 is a statistical term defining that $95 \%$ will have LOC at this BIS value. In this study the Bis 95 for male patients was equal to 55 (95\% CI: $53-56)$ in the 0.0 group, 57 (95\% CI:55-59) in the 0.4 group, 57 (95\% CI: $54-58$ ) in the 0.6 group and 58 (95\% CI: 55-60) in the 0.8 group. The $\mathrm{BIS}_{95}$ for female patients was 56 (95\% CI: 54-57) in the 0.0 group, 58 (95\% CI:54-59) in the 0.4 group, 59 (95\% CI: 58-61) in the 0.6 group and 59 (95\% CI: $56-61)$ in the 0.8 group. No significant differences between gender groups were found $(P>0.05)$ (• Table 4).

\section{Discussion}

Propofol is a common hypnotic-sedative drug with rapid onset and offset of effect; however, when used alone it causes dose dependent cardiorespiratory depression [17]. Various adjunct medications including opioids, benzodiazepines and $\alpha_{2}$ agonists have been employed as coinduction agents to change the adverse effects of propofol. $[18,19]$. Dexmedetomidine is frequently used to reduce propofol requirement during propofol anesthesia. This study compared gender difference on the propofol-sparing effect of dexmedetomidine after pretreatment with different concentrations. The primary outcome parameter studied was the calculated effect-site median effective concentration $\left(\mathrm{EC}_{50}\right.$ ) of propofol after pretreatment with different concentrations of dexmedetomidine. The $\mathrm{EC}_{50}$ of propofol is defined as the effect site concentration at which $50 \%$ of patients experience loss of consciousness (LOC). It was found that there were no significant differences in the plasma $\mathrm{EC}_{50}$ of dexmedetomidine between males and females (2.06 vs. $2.09 \mathrm{ng} / \mathrm{ml} ; p>0.05)$. There were, however, significant gender differences between the calculated effect-site $\mathrm{EC}_{50}$ of propofol. Males required higher calculated effect-site $\mathrm{EC}_{50}$ than females in all 4 groups of $0.0,0.4$, 0.6 and $0.8 \mathrm{ng} / \mathrm{ml}$. This is consistent with Kodaka et al. who found simi- 
Table 4 The mean BIS values (confidence interval) at which patients had a $95 \%$ probability of LOC

\begin{tabular}{|l|l|l|l|l|}
\hline & $\mathbf{0 . 0}$ group & $\mathbf{0 . 4}$ group & $\mathbf{0 . 6}$ group & $\mathbf{0 . 8}$ group \\
\hline Male & $55(53-56)$ & $57(55-59)$ & $57(54-58)$ & $58(55-60)$ \\
\hline Female & $56(54-57)$ & $58(54-59)$ & $59(58-61)$ & $59(56-61)$ \\
\hline BIS bispectral index, LOC loss of consciousness & & \\
\hline
\end{tabular}

lar results that males patients needed significantly higher propofol concentrations to achieve LOC than females (2.9 vs. $2.7 \mu \mathrm{g} / \mathrm{ml} p<0.05$ ) [6]. Another study also reported that male patients required higher calculated effect-site $\mathrm{EC}_{50}$ of propofol during i-gel (LMA) insertion after pretreatment with $0.5 \mu \mathrm{g} / \mathrm{kg}$ of dexmedetomidine $(5.46$ vs. $3.82 \mu \mathrm{g} / \mathrm{ml}$, $P<0.01$ ) [8]. In contrast to the study by Choi et al. different concentrations of dexmedetomidine were preadministered, namely $0.0,0.4,0.6$, and $0.8 \mathrm{ng} / \mathrm{ml}$ over 15 mins before starting a TCI infusion of propofol to achieve an initial effect-site concentration of $1.0 \mu \mathrm{g} / \mathrm{ml}$. This was followed by increments of $0.2 \mu \mathrm{g} / \mathrm{ml}$ until the clinical end point of LOC was confirmed. Rapid administration of the induction dose of propofol is associated with a significant reduction in blood pressure of approximately $20-40 \%$. Thus, the effect site $\mathrm{EC}_{50}$ of propofol was gradually increased [20].

According to the mechanistic model, the pharmacodynamic interactions of dexmedetomidine and propofol for induction of LOC were additive regardless of gender. No significant differences were found between genders for plasma EC $_{50 \mathrm{~d}}$ of dexmedetomidine. (- Table 3) Dexmedetomidine induces hyperpolarization of noradrenergic locus ceruleus neurons to enhance eye movement sleep promoting pathways to achieve sedation. [21]. As found in a recent study by Zhao et al. [10], this study showed that dexmedetomidine significantly and dose-dependently decreased the calculated effect-site $\mathrm{EC}_{50}$ of propofol and BIS values during anesthesia induction. The findings contrast with a previous study which concluded that the calculated effect-site $\mathrm{EC}_{50}$ of propofol required to produce adequate anesthesia for esophagoduodenoscopy (EGD) in children was unaffected by a concomitant infusion of dexmedetomidine
$1 \mu \mathrm{g} / \mathrm{kg}$ given over $10 \mathrm{~min}$ [22]. It is possible that the concomitant administration of propofol and dexmedetomidine in the study did not allow adequate time for dexmedetomidine to exert a propofol-sparing effect. It may also well be that dexmedetomidine lacks a propofolsparing effect in the pediatric population. Further research will be elucidative.

The sedative effect of dexmedetomidine has been shown to be more significant in female patients during the luteal phase of menstrual cycles than the follicular phase [23]. Progesterone and its metabolites are known to have sedative, anxiolytic, analgesic and anticonvulsant effects [24-26]. A recent study demonstrated that the progesterone levels were inversely correlated with the calculated effect site $\mathrm{EC}_{50}$ of propofol [27]. Propofol and progesterone share similar mechanisms of action through the gammaaminobutyric acid type $\mathrm{A}\left(\mathrm{GABA}_{\mathrm{A}}\right)$ receptor, which is known to be among the major binding sites for several general anesthetics [28, 29]. Hence the propofol-sparing effect during the luteal phase is most likely an additive effect given that the luteal phase has progesterone dominance and so dexmedetomidine will exert a more sparing effect on propofol. In contrast, another study found that intraoperative administration of dexmedetomidine had a stronger morphine-sparing effect in postoperative pain control in males compared to females [30]. A possible mechanism for this finding is unknown although animal studies implicated estrogen which is believed to attenuate $\alpha_{2}$ adrenergic receptor-mediated analgesia [31]. This study, just like the present study, did not account for the menstrual cycle phases of the female participants.

The bispectral index was introduced by Aspect Medical System in 1994 to facilitate objective evaluation of depth of sedation [32]. It assesses the level of consciousness by algorithm analysis of patient's electroencephalographic data during general anesthesia [33]. This study did not find an effect of gender on the BIS $_{95}$ values for LOC as defined (- Table 4). This is consistent with a previous study which showed that men and women had equivalent BIS values at $\mathrm{LOC}_{50}$ [6]. Therefore, the BIS can be used to monitor depth of anesthesia and anesthetic dosing and to avoid an unnecessary deep anesthetic state as well as an increased risk of awareness during combined propofol/dexmedetomidine anesthesia.

This study has certain limitations. First, higher concentrations of dexmedetomidine were not used as these concentrations are known to increase pulmonary arterial pressure and vascular resistance which will lead to bradycardia and hypotension [34-36]. Thus, a maximum of $0.8 \mathrm{ng} / \mathrm{ml}$ plasma concentration of dexmedetomidine was used to avoid serious cardiovascular effects. Second, plasma drug concentrations of propofol and dexmedetomidine were not measured. Predicted concentrations were used for data analysis. Last, the study did not account for the menstrual cycle phase of the female study participants.

In conclusion, the present study shows that gender has association with the calculated effect-site $\mathrm{EC}_{50}$ of propofol for LOC (defined as OAA/S score $<2$ ) after pretreatment with different concentrations of dexmedetomidine. According to this, gender should be considered when these drugs are co-administered during anesthesia induction.

\section{Corresponding address}

\section{Bo Xu, MD}

Department of Anesthesiology, General Hospital of Southern Theatre Command of PLA 510010 Guangzhou, China

xubo333@hotmail.com

Funding. The study was supported by the $\mathrm{Na}$ tional Natural Science Foundation of China (grant number 61773130), the Science and Technology Project of Guangdong Province (grant number 2014A020215026) and the General Programme of Military Logistics Scientific Research Plan (grant numbers CGZ15C003, CWH17J024).

Authors' contributions. Ming Xiong participated in study design, data analysis, and data interpretation. 
Zhao-Xin Zheng participated in literature search, data collection, data analysis, data interpretation and wrote the manuscript. Zu-Rong Hu participated in data analysis and critical revision. Jing He participated in data analysis and data interpretation. Uchenna Madubuko and Dennis Grech conceived the study and participated in its design and coordination. Xing-An Zhang carried out the data collection and analysis. Bo Xu participated in study design, data collection, and provided the critical revision. All authors read and approved the final manuscript.

\section{Compliance with ethical guidelines}

Conflict of interest. M. Xiong, Z.-X.Zheng, Z.-R. Hu, J. He, U. Madubuko, D. Grech, X.-A. Zhang and B. Xu declare that they have no competing interests.

All procedures performed in studies involving human participants were in accordance with the ethical standards of the institutional and/or national research committee and with the 1975 Helsinki declaration and its later amendments or comparable ethical standards. This study was conducted with written informed consent from the study subjects.

Open Access This article is distributed under the terms of the Creative Commons Attribution 4.0 International License (http://creativecommons.org/licenses/by/ 4.0/), which permits unrestricted use, distribution, and reproduction in any medium, provided you give appropriate credit to the original author(s) and the source, provide a link to the Creative Commons license, and indicate if changes were made.

\section{References}

1. Kumari K, Gombar S, Kapoor D, Sandhu HS (2015) Clinical study to evaluate the role of preoperative dexmedetomidine in attenuation of hemodynamic response to direct laryngoscopy and tracheal intubation. Acta Anaesthesiol Taiwanica 53(4):123-130

2. Kunisawa T, Nagata O, Nagashima M, Mitamura S, Ueno M, Suzuki A, Takahata O, Iwasaki H (2009) Dexmedetomidine suppresses the decrease in blood pressure during anesthetic induction and blunts the cardiovascular response to tracheal intubation. JClin Anesth 21(3):194-199

3. Liu Y, Ma L, Gao M, Guo W, Ma Y (2016) Dexmedetomidine reduces postoperative delirium after joint replacement in elderly patients with mild cognitive impairment. Aging Clin Exp Res 28(4):729-736

4. Le Guen M, Liu N, Tounou F, Augé M, Tuil O, Chazot T, Dardelle D, Laloë PA, Bonnet F, Sessler D, Fischler M (2014) Dexmedetomidine reduces propofol and remifentanil requirements during bispectral index-guided closed-loop anesthesia: a doubleblind, placebo-controlled trial. Anesth Analg 118(5):946-955

5. Pleym H, Spigset O, Kharasch ED, Dale O (2003) Gender differences in drug effects: implications for anesthesiologists. Acta Anaesthesiol Scand 47:241-259

6. Kodaka M, Johansen JW, Sebel PS (2005) The influence of gender on loss of consciousness with sevoflurane or propofol. Anesth Analg 101:377-381
7. Arya S, Asthana V, Sharma JP (2013) Clinical vs. Bispectral index-guided Propofol induction of anesthesia: a comparative study. Saudi J Anaesth 7:75-79

8. Choi JJ, Kim JY, Lee D, Chang YJ, Cho NR, Kwak HJ (2016) Male patients require higher optimal effect-site concentrations of propofol during i-ge insertion with dexmedetomidine $0.5 \mu \mathrm{g} / \mathrm{kg}$. BMC Anesthesiol 16(1):20

9. Chen Z, Shao DH, Hang LH (2013) Effects of dexmedetomidine on performance of bispectral index as an indicator of loss of consciousness during propofol administration. Swiss Med Wkly 143:w13762

10. Zhao XN, Ran JH, Bajracharya AR, Ma MY (2016) Effect of different doses of dexmedetomidine on median effective concentration of propofol for anesthesia induction: a randomized controlled trial. Eur Rev Med Pharmacol Sci 20(14):3134-3143

11. Schnider TW, Minto CF, Gambus PL, Andresen C, Goodale DB, Shafer SL, Youngs EJ (1998) The influence of method of administration and covariates on the pharmacokinetics of propofol in adult volunteers. Anesthesiology 88:1170-1182

12. Schnider TW, Minto CF, Shafer SL, Gambus PL, Andresen C, Goodale DB, Youngs EJ (1999) The influence of age on propofol pharmacodynamics. Anesthesiology 90:1502-1516

13. Angst MS, Ramaswamy B, Davies MF, Maze $M$ (2004) Comparative analgesic and mental effects of increasing plasma concentrations of dexmedetomidine and alfentanil in humans. Anesthesiology 101:744-752

14. Lin TY, Lo YL, Hsieh CH, NiYL, Wang TY, Lin HC, Wang $\mathrm{CH}, \mathrm{Yu}$ CT, Kuo HP (2013) The potential regimen of target-controlled infusion of propofol in flexible bronchoscopy sedation: a randomized controlled trial. PLoSONE 8(4):e62744

15. Lysakowski C, Elia N, Czarnetzki C, Dumont L, Haller G, Combescure C, Tramèr MR (2009) Bispectral and spectral entropy indices at propofol-induced loss of consciousness in young and elderly patients. $\mathrm{BrJ}$ Anaesth 103:387-393

16. Vuyk J, Engbers FH, Burm AG, Vletter AA, Griever GE, Olofsen E, Bovill JE (1996) Pharmacodynamic interaction between propofol and alfentanil when given for induction of anesthesia. Anesthesiology 84:288-299

17. Yousef GT, Elsayed KM (2013) A clinical comparison of ketofol (a ketamine and Propofol admixture) versus Propofol as an induction agent on quality of insertion of laryngeal mask airway insertion and hemodynamic stability in children. Anesth Essays Res 7(2):194-199

18. Cheam EWS, Chui PT (2000) Randomised doubleblind comparison of Fentanyl, mivacurium or placebo to facilitate laryngeal mask airway insertrion. Anaesthesia 55:323-326

19. Begec Z, Demirbilek S, Onal D, Erdil F, IlksenToprak H, Ozcan Ersoy M (2009) Ketamine or alfentanil administration prior to propofol anaesthesia: the effects on ProSeal TM laryngeal mask airway insertion conditions and haemodynamic changes in children. Anaesthesia 64(3):282-286

20. DukeT (1995) A new intravenous anesthetic agent: propofol. Can Veterinary J36(3):181-183

21. Kasuya Y, Govinda R, Rauch S, Mascha EJ, Sessler DI, Turan A (2009) The correlation between bispectral index and observational sedation scale in volunteers sedated with dexmedetomidine and propofol. Anesth Analg 109:1811-1815

22. Hammer G, Sam W, Chen M, Golianu B, Drover D (2009) Determination of the pharmacodynamic interaction of Propofol and dexmedetomidine during esophagogastroduodenoscopy in children Pediatr Anesth 19:138-144

23. Han C, Ge S, Huang S, Lu Y (2016) Influence of different menstrual phases on the Bispectral Index during dexmedetomidine sedation. Kaohsiung J Med Sci 32:586-592

24. van Broekhoven F, Backstrom T, Verkes RJ (2006) Oral progesterone decreases saccadic eye velocity and increases sedation in women. Psychoneuroendocrinology 31:1190-1199

25. Soderpalm AH, Lindsey S, Purdy RH, Hauger $\mathrm{R}_{\text {, }}$ de Wit $\mathrm{H}$ (2004) Administration of progesterone produces mild sedative-like effects in men and women. Psychoneuroendocrinology 29:339-354

26. Lancel M, Faulhaber J, Holsboer F, Rupprecht R (1996) Progesterone induces changes in sleep comparable to those of agonistic GABAA receptor modulators. Am JPhysiol 271:E763-E772

27. Fu F, Chen X, Feng Y, Shen Y, Feng Z, Bein B (2014) Propofol EC50 for inducing loss of consciousness is lower in the luteal phase of the menstrual cycle. $\mathrm{Br}$ JAnaesth 112:506-513

28. Bali M, Akabas MH (2004) Defining the propofol binding site location on the GABAA receptor. Mol Pharmacol 65(1):68-76

29. Liu YW, Zuo W, Ye JH (2013) Propofol stimulates noradrenalin-inhibited neurons in the ventrolateral preoptic nucleus by reducing GABAergic inhibition. Anesth Analg 117(2):358-363

30. Li Y, Ge D, Li J, Qi B (2016) Sex differences in the Morphine-Sparing Effects of Intraoperative Dexmedetomidine in patient-controlled analgesia following general anesthesia. Medicine 95(18):e3619

31. Thompson AD, Angelotti T, Nag S et al (2008) Sex-specific modulation of spinal nociception by alpha2-adrenoceptors: differential regulation by estrogen and testosterone. Neuroscience 153:1268-1277

32. Sahinovic MM, Eleveld DJ, Kalmar AF, Heeremans $\mathrm{EH}$, De Smet T, Seshagiri CV, Absalom AR, Vereecke $H$, Struys M (2014) Accuracy of the composite variability index as a measure of the balance between nociception and antinociception during anesthesia. Anesth Analg 119:288-301

33. Sigl JC, Chamoun NG (1994) An introduction to bispectral analysis for the electroencephalogram. JClin Monit 10:392-404

34. Ebert TJ, Hall JE, Barney JA, Uhrich TD, Colinco MD (2000) The effects of increasing plasma concentrations of dexmedetomidine in humans. Anesthesiology 93(8):382-394

35. Dutta S, Lal R, Karol MD, Cohen T, Ebert T (2000) Influence of cardiac output on dexmedetomidine pharmacokinetics. JPharm Sci 89(4):519-527

36. Peden CJ, Cloote AH, Stratford N, Prys-Roberts C (2001)Theeffect of intravenous dexmedetomidine premedication on the dose requirement of propofol to induce loss of consciousness in patients receiving alfentanil. Anaesthesia 56(5):408-413 